\title{
ETNICIDADE EM QUESTÃO NO SÉCULO IV A.C.: O DISCURSO PAN-HELÊNICO E O COSMOPOLITISMO CÍNICO-ESTOICO
}

\author{
Luis Felipe Bellintani Ribeiro ${ }^{1}$ \\ Roberto Torviso Neto ${ }^{2}$
}

\begin{abstract}
Resumo: $\mathrm{O}$ conceito de "cidadão do mundo" foi reinventado na modernidade, como parte de um projeto de mundo humanista. Foi na antiguidade, porém, que, segundo Diógenes Laércio e outros, Diógenes o cínico pela primeira vez se declarou kosmopolites. O conceito foi depois enfatizado pelos estoicos, em especial Sêneca e Musônio Rufo. Alguns historiadores tendem a ver a campanha de Alexandre Magno como a aplicação do projeto de cidade universal no mundo conhecido. Este texto tem por objetivo problematizar algumas questões concernentes ao cosmopolitismo helenístico, do ponto de vista histórico-factual e quanto à sua concepção intelectual e teórica.

Palavras-chave: Cinismo, cosmopolitismo, pan-helenismo, identidade, Grécia Clássica.
\end{abstract}

\section{INTRODUÇÃo}

O século IV a.C. é testemunha de uma reviravolta na organização geopolítica do leste mediterrâneo quando Felipe da Macedônia subjuga as póleis ao sul como resultado da Batalha de Queroneia (338 a.C.) e, poucos anos depois, Alexandre Magno derruba o Império Aquemênida ao longo de sua campanha na Ásia. Neste processo leva literamente sob o braço a cultura grega, visto que era leitor ávido de Homero e fora instruído por ninguém menos do que Aristóteles, tendo companhia também, em suas expedições, de sábios e intelectuais da Hélade os quais pôs em contato com os sábios e magos

1 Professor do Departamento de Filosofia e do Programa de Pós-Graduação em Filosofia (PGFI) da Universidade Federal Fluminense. Membro dos seguintes grupos de pesquisa: Núcleo de Filosofia Antiga (UFF), Laboratório OUSIA (UFRJ), Núcleo de Filosofia Antiga (UFSC), e Filosofia, Arte e Educação (UFSC). Contato: lfbribeiro@id.uff.br

2 Mestrando pelo Programa de Pós-Graduação em Filosofia da Universidade Federal Fluminense. Licenciado em História pelo Centro Universitário La Salle. Membro do Grupo de Estudos Kemet vinculado ao Centro de Estudos Interdisciplinares da Antiguidade (GEKEMET/CEIA-UFF). Contato: torvisohistoria@gmail.com 
orientais. Entretanto, a tradição historiográfica trata a expansão macedônica contra os persas como a expressão última de um pan-helenismo, alega que a monarquia universal era um objetivo da campanha desde o início desta empreitada e que o "amálgama final das raças" deste novo império helenístico pôs fim à oposição entre civilização e barbárie através do ideal da fraternidade universal pregada pelos filósofos estoicos. Estes três pontos - o pan-helenismo, a falácia da monarquia universal e o cosmopolitismo cínico-estoico - serão trabalhados neste artigo que questiona o quão universal se propunha o império alexandrino e seus respectivos sucessores.

\section{A falácia da Monarquia Universal}

O historiador Pierre Lévêque (1921-2004), renomado helenista do século $\mathrm{XX}$, publicou um livro sobre o período helenístico traduzido pela portuguesa Editora 70 com o título O mundo belenistico (1987). Nele percebemos a ótica romanceada através da qual Lévêque enxerga a expansão alexandrina e seus desdobramentos, seja pelo emprego de metáforas, ao se referir a Alexandre Magno, tomadas de fenômenos naturais que assolam tanto a Hélade quanto o Oriente Próximo, seja pela ideia de monarquia universal que Lévêque sustenta desde as primeiras páginas, que seria a intenção por trás da "marcha para o Leste". O helenista defende que o empreendimento militar e expansionista promovido por Felipe II e seu sucessor Alexandre Magno objetivou desde seu início formar e consolidar um reinado de proporções cósmicas dominando todo o mundo conhecido. Podemos entender o conceito de monarquia universal empregado por Lévêque também como ruptura com a antiga oposição entre civilização e barbárie, bem como a defesa naquele tempo de uma fraternidade universal entre povos e classes sociais. Esta análise das mudanças promovidas pelo período helenístico é apresentada também por Giovanni Reale e Dante Antiseri em sua História da Filosofia Ocidental (2003) conforme exposto no parágrafo a seguir.

A expansão de Alexandre o Grande e a fusão com o Oriente Próximo póem fim à organização em cidades-estados, substituindo-a pelo sonho da monarquia universal (Cf. LÉVÊQUE, 1987) por meio da união entre os diversos povos do mar mediterrâneo, principalmente através de casamentos estratégicos entre os generais macedônicos e princesas orientais, em especial no Egito e na Pérsia. Somando a isso o afastamento da população dos assuntos políticos, o desmoronamento das diferenças racistas entre gregos e bárbaros - que foram acolhidos numa política de assimilação e equiparação aos gregos por Alexandre - e a descoberta de si enquanto indivíduo teremos como 
consequência a aporia maior do pensamento grego até então, já que, com isso, as teorias de Platão e Aristóteles tornam-se insuficientes, não de modo geral, mas em particular na filosofia política (REALE, 2003, p. 250-252).

Com relação à questão dos bárbaros na Antiguidade Clássica, Zanella faz uma observação interessante quando discorre sobre o conceito de pólis:

Por fim, as observações de Platão sobre os bárbaros na República (469b-471c), e aquelas de Aristóteles (384-322 a.C.) na Política $(1281 b ; 1285 a)$ constituem outra prova bastante evidente de quão pouco interesse houve para com o cosmopolitismo na Grécia clássica, pois a identidade das repúblicas se configurava, por vezes, graças ao contraste com os bárbaros (ZANELLA, 2014, p. 171).

De fato o autor foi muito feliz em sua colocação, pois é com base nessa oposição entre civilização (grega) e barbárie que os gregos sustentam um ideal de superioridade tal como se percebe em Heródoto quando ele justifica a vitória dos atenienses sobre os persas nas Guerras Medo-Pérsicas alegando que seus deuses era maiores que o deus-rei Xerxes e, portanto, foram os gregos os vitoriosos, isso porque eles são melhores que os persas. No mundo helenístico, esta diferença se apaga, pois, como apresenta Lévêque:

Imagina-se o poderoso fermento de unificação social que elas [as confrarias] representam: ao mundo clássico, onde a oposição entre Grego e Bárbaro ou entre cidadão e escravo é absoluta, onde a mulher é razoavelmente desprezada, sucede um mundo novo onde os antagonismos se apagam (LÉVÊQUE, 1987, p. 159).

É importante também frisar o aspecto do afastamento das pessoas comuns das decisões políticas. Sobre essa mudança radical na práxis política, ao menos pelo lado ocidental, Reale faz uma observação interessante:

De "cidadão", no sentido clássico do termo, o homem grego torna-se "súdito". A vida nos novos Estados se desenvolve independentemente do seu querer. [...] O administrador da coisa pública torna-se funcionário, soldado ou mercenário. E, ao lado deles, nasce o homem que, não sendo mais nem o antigo cidadão nem o novo técnico, assume diante do Estado uma atitude de desinteresse neutro, quando não de aversão (REALE, 2003, p. 250).

Isso parece óbvio, mas ao afastar o antigo cidadão da ágora, isto é, do espaço das discussões e das decisóes referentes à gestão da cidade, a práxis política do mundo helenístico rompe com a tradição grega; o que é mais 
intrigante pelo fato de Alexandre ter sido aluno de Aristóteles durante toda sua vida. $\mathrm{O}$ dia-a-dia nos estados ocorre sem a participação ativa do homem livre e, ao não dar-lhe uma ocupação secundária do estado, como funcionário ou soldado, é de se esperar o surgimento de um homem alheio à política. Contudo, não parece adequado entender uma pessoa alheia à política como uma pessoa não politizada. Epicuro, por exemplo, recomendava a seus discípulos que se mantivessem distantes o máximo possível da política, mas, ao dizê-lo, não o diz sem fundamento, nem sem propor outras formas de liame entre os homens, como a amizade. Nas palavras de Souza e Pereira Melo, para Epicuro, outro filósofo do período, "a verdadeira eudaimonia não estava nas atividades exteriores e nas vãs opiniões da sociedade grega, mas particularmente na própria interioridade do ser humano consigo mesmo e com o seu próximo", sendo por essa visão da felicidade plena do homem que o "filósofo da alegria" (como alguns o chamam) sugeria a seus amigos que se distanciassem dos jugos políticos (Cf. SOUZA, PEREIRA MELO, 2011).

Em outra passagem, Reale destaca a incongruência da teoria política clássica com relação à nova condição histórica da civilização grega, especificamente as teorias de Platão e Aristóteles, a seguir:

Encontravam-se assim destruídos aqueles valores fundamentais da vida espiritual da Grécia clássica, que constituíam o ponto de referência do agir moral e que Platão, na sua República, e Aristóteles, na sua Política, não só teorizaram, mas também sublimaram e hipostasiaram, fazendo da pólis não apenas uma forma histórica, mas inclusive a forma ideal do Estado perfeito. Como consequência, aos olhos de quem visse a revolução de Alexandre, essas obras perdiam seu significado e vitalidade, aparecendo imprevistamente em dissonância com os tempos e colocando-se em perspectiva superada (REALE, 2003, p. 250).

Tal obsolescência do pensamento político àquela época faz com que as escolas filosóficas helenísticas, sendo algumas fundadas por ex-alunos de Sócrates e Platão, se proponham a encarar não mais uma relação do homem para com a cidade e seus concidadãos, mas sim uma relação do indivíduo com o cosmos. Sobre a consciência de si enquanto ser autônomo, isto é, a descoberta do indivíduo foi tão revolucionária que, nas palavras de Reale (2003): “... na descoberta do indivíduo cai-se, às vezes, nos exageros do individualismo e do egoísmo. Mas a revolução tinha tal importância que não era fácil mover-se com equilíbrio na nova direção". Duas das escolas helenísticas, o cinismo, cujo patrono é Antístenes, um ex-aluno de tanto de Górgias quanto de Sócrates, e o estoicismo, fundado por Zenão, possuem representantes que, de algum modo, promoveram posturas alternativas à inércia da cidadania em crise. 
No entanto, pelo que as fontes consultadas indicam a formação e duração do império helenístico não foi bem assim. A análise de Peter Green exposta na obra Alexandre, o Grande e o período helenístico (2014) traz nova luz a este debate com relação ao período mencionado, mais ainda quando aborda a questão do pan-helenismo no empreendimento alexandrino rumo ao oriente, embora limite seu comentário a algumas páginas iniciais e sempre concatenando com a abordagem político-militar. As relações entre a Macedônia e a Liga de Corinto, união de boa parte das póleis forçada por Felipe II, não eram boas. Às vésperas de atravessar o Egeu, Alexandre se vê forçado a retornar à Grécia por conta de rebelióes lideradas por Tebas e Atenas desencadeadas pelo boato propagado por Demóstenes afirmando que Alexandre e suas tropas foram massacrados por trácios. Se havia interesse, se não dedo, dos persas neste conluio, não é difícil deduzir, visto que Diodoro Siculo conta que os tebanos convocam "qualquer um que desejasse, junto com o Grande Rei [da Pérsia] e os tebanos, libertar os gregos e destruir o tirano da Grécia" (grifos nossos) para unirem-se a eles.

Green relata que diante de uma ameaça persa e da afronta como tirano, sendo desprezado como tal, Alexandre instiga a Liga de Corinto à seguinte decisão contra Tebas: "assolar a cidade, ver os prisioneiros, declarar fora da lei os fugitivos em toda a Grécia e proibir que os helenos lhes oferecessem abrigo" (2014, p. 42). Podemos discutir as implicações deste último ponto para com a xenía, a hospitalidade mandatória na cultura grega, em outra ocasião. $\mathrm{O}$ resultado, custoso para Alexandre em longo prazo, acabou por dissuadir as outras póleis em rebelião e, desejando solucionar a questão grega o quanto antes, deixou de lado a perseguição aos opositores e tratou o problema por meio de acordos. A "solução final" contra Tebas finda, muito provavelmente, qualquer esperança de defesa do pan-helenismo como um fator para a expansão. De fato, não apenas uma das principais póleis do momento é arrasada enquanto as outras são coagidas ao subjugo dos macedônios como também havia uma tensão entre os ânimos de ambos os lados, marcada por desprezo mútuo. Conforme diz Green:

Por fora, os gregos colaboravam. Por dentro, sua atitude passou a ser de ódio amargo e implacável: foi para mantê-los subjugados, e não apenas as tribos fronteiriças, que um exército macedônico, pouco menor que a força expedicionária de Alexandre, foi deixado para trás na Europa. Além disso, comparativamente, poucas tropas gregas serviram na expedição em si, e nenhuma na linha de frente; mesmo estas foram eliminadas assim que surgiu o momento oportuno. Nenhum grego continental jamais foi designado governador regional (sátrapa) por Alexandre. [...] Eles se desprezavam, corretamente ou não, como 
estrangeiros que (supostamente) falavam línguas diferentes; essa xenofobia era intensificada, do lado grego, pelo desdém intelectual mesclado a um amargo sentimento de derrota, e do lado macedônico, por um medo constante de más intenções e rebelião (GREEN, 2014, p. 42-43).

Percebe-se então a partir da análise de Peter Green que a intelectualidade grega ainda era um fator decisivo na oposição entre gregos e bárbaros que, ao contrário do que Lévêque e Reale alegam, não foi superada. $\mathrm{O}$ autor vai além, afirmando que foi esse "amálgama final de raças, no último ano ou dois de sua vida, que levou alguns idealistas a dizerem que Alexandre estava buscando uma irmandade estoica entre os homens, mas entre macedônios e persas: os gregos não participaram dela em lugar algum" (GREEN, 2014, p. 42).

\section{O Cosmopolitismo Antigo}

O cosmopolitismo enquanto termo tem seu registro mais antigo quando Diógenes Laércio relata que seu homônimo cínico teria proferido este termo pela primeira vez. E sendo o estoicismo e o epicurismo em certa medida derivados do movimento ć́nico - o primeiro pela busca de uma vida feliz por meio do exercício da virtude enquanto o segundo por sua moderação dos prazeres e de ambos a objetivação do controle de si (autarquia) - parece-nos plausível que este ideal do mundo como cidade universal seja algo característico das novas filosofias surgidas durante o período helenístico enquanto alternativa à crise da política pautada nas cidades-estados.

Ainda que Diógenes tenha sido supostamente o primeiro a empregar o termo, o ideal é anterior a ele, havendo alguns entre os gregos que já criticavam o tradicional aspecto identitário pautado no pertencimento a um local de origem. Exemplo disso é o sofista Hípias tal como é apresentado no diálogo Protágoras no qual uma fala demasiado peculiar (337c-d) chama-nos atenção:

Então depois de Pródico ter falado assim, muitos - muitos mesmo - dos presentes o apoiaram. A seguir a Pródico falou o sábio Hípias: - Senhores aqui reunidos, sou de opinião que todos nós somos parentes, amigos e concidadãos, não por força da lei, mas pela natureza; porque o semelhante é por natureza igual ao semelhante; ao passo que a lei, como tirana que é dos homens, violenta muitas vezes a natureza (PLATÃO, Protágoras, 337c-d).

Quanto a Sócrates, pensador ao qual o estoico Musônio Rufo se refere, discute-se ainda se e até que ponto seu filosofar pode ser definido como 
cosmopolita. Eric Brown defende que Sócrates deve ser considerado como um cosmopolita moderado porque, apesar de reconhecer certas obrigaçóes para com os atenienses e deste modo exercitar a política "tradicional", este dever para com os atenienses é tão somente uma parte de seu dever maior para com a humanidade de modo geral. Nas palavras do pesquisador:

Recordemos que Sócrates não rejeita por inteiro a política "ordinária", uma vez que ele atende ao chamado de Atenas por três ou quatro vezes $\left[{ }^{1}\right]$. Além disso, as Leis do Críton nos rememoram que a carreira de Sócrates na política "extraordinária" foi dedicada por completo a Atenas. Tais fatos sugerem que cosmopolitismo de Sócrates é fortemente enraizado em sua cidadania ateniense e que sua obrigação em prestar serviço extraordinário aos seres humanos está condicionada pelo menos a suas obrigações para com seus concidadãos (BROWN, 2000, p. 81).

A questão que Brown indaga na quarta parte de seu artigo é: por que então Sócrates concentra em Atenas o esforço de sua política "extraordinária" quando ele admite que suas obrigações são para com a humanidade e também ele não reconhece nenhuma obrigação especial para com os atenienses? Esta quarta parte é chamada brilhantemente Thinking globally, acting locally, dando uma pista quanto ao palpite do autor. Para ele, a dialética como purificação das almas possui também uma finalidade política, pois aquele que conhece o Bem é necessariamente o mais adequado para bem administrar a cidade e se a dialética é um exame pessoal, é razoável deduzirmos que a reformulação da política deve partir do singular e gradativamente expandir-se até que a humanidade por inteiro alcance o estado perfeito de vida. No momento em que a pólis examinar a si mesma e perceber suas falhas, chegando à crise aporética, ela poderá então purificar-se modificando aquilo que deve ser redefinido do mesmo modo que os interlocutores de Sócrates se deram conta de que suas falsas opiniões deveriam ser repensadas.

De todo modo, a discussão sobre Sócrates ter sido ou não cosmopolita é pormenorizada, uma vez que é majoritariamente aceito que suas ideias influenciaram bastante a formação das escolas helenísticas que tinham como ponto comum um espírito cosmopolita em suas doutrinas (se é que podemos falar de doutrina no cinismo e no pirronismo). Com Diógenes, o Cínico, teremos a expressão clara do conceito de cosmopolitismo com o emprego do próprio termo quando diz: "kosmopolites eimi" - "Sou um cidadão do mundo" (D.L., VI, 63). Esta fala é interpretada como cosmopolitismo negativo no sentido de que Diógenes nega a pólis. A pergunta que se faz é se haveria 
algo de positivo nesta afirmação. No verbete "cosmopolitismo" da Stanford Encyclopedia of Philosophy os autores Eric Brown e Pauline Kleingeld sugerem que o que se pode ver de positivo no cosmopolitismo de Diógenes é justamente a insistência que o mundo inteiro deveria seguir o modo de vida cínico.

$\mathrm{Na}$ chamada fase imperial, isto é, quando as filosofias helenísticas não importadas por Roma, os estoicos foram os principais adeptos desta cosmovisão do mundo-Estado. Temos então o caso de Musônio Rufo (25 d.C. -95 d.C), autor de diversas diatribes dentre as quais destaca-se para esta pesquisa a IX intitulada "Que o exílio não é um mal" (Ek tou oti ou kakón hé phýge ). Nela o estoico interroga claramente: "Mas diga-me, não é o mundo inteiro pátria comum dos homens tal como alegava Sócrates?”. Quer Sócrates considerasse de fato o mundo inteiro como uma pólis universal ou não, visto que de Sócrates nenhum registro autoral chegou até nós, é um detalhe chamativo que nas escolas helenísticas encontremos esta cosmovisão atribuída ao mesmo. De todo modo, sucessivo a esta indagação, Musônio Rufo declara que um homem não deveria "se considerar verdadeiramente exilado de sua cidade natal se partir do lugar onde nasceu e foi criado, mas apenas banido de uma cidade específica, isto, claro, caso se considere uma pessoa razoável". Justifica seu argumento da seguinte forma:

Isso porque tal homem não enaltece nem deprecia coisa alguma como causa (aitía) da felicidade (eudaimonía) - ou da infelicidade (kakodaimonía) - e ele faz com que tudo dependa dele mesmo considerando-se um cidadão da cidade de Zeus que é formada por homens e deuses. Eurípides dizia o mesmo em harmonia deste modo:

"Enquanto o céu estiver aberto para o voo da águia

A terra será pátria para o homem de valor."

(MOUSONIUS RUFUS, Diatribes, IX, 3)

O tema da diatribe IX - a indiferença para com o exílio - aparece também na consolatio de Sêneca a sua mãe Hélvia, redigida durante seu exílio promovido pela acusação de adultério junto a Júlia Lívia, sobrinha do imperador Cláudio. Diz-se que o monarca já nutria um desafeto para com o filósofo estoico, o que atribui um caráter político e pessoal à condenação. Consola-a pelo fato de, após diversos sofrimentos, ser contemplada com mais um: o exílio de Sêneca. Conforme traduzida a carta: "Faz pouco tempo que recolhestes os ossos de três netos [...]; e vinte dias depois de celebrar o enterro de meu filho, [...], tiveste a notícia de meu exílio. Somente isso te faltava até agora: chorar os vivos" (SÊNECA, Consolação a minha mãe Hélvia, II, 5). Dizer que só resta chorar pelos vivos sugere que o exílio seja como motivo de sofrimento tanto para os entes queridos quanto para o exilado. $\mathrm{O}$ objetivo da consolatio era, como expresso na mesma, 
vencer tua dor, não iludi-la. E vencê-la-ei, creio eu, se conseguir demonstrar antes de tudo que não sofre por nenhuma razão a respeito da qual eu poderia ser chamado mísero [...]; depois demonstrarei, passando a ti, que nem tua sorte, que em tudo está ligada à minha, pode ser considerada infeliz. Começarei dizendo que eu não tenho mal algum. Se puder, demonstrar-teei como também as coisas que tu pensas que me aniquilam com seu peso não são nem elas intoleráveis (SÊNECA, Consolação a minha mãe Hélvia, , IV, 1-2).

Não ignoramos os infortúnios do degredo, como Sêneca também não fez. Num mundo onde o coletivo significava segurança e o exílio não a toa era uma punição, ele teria que domar a terra inóspita para sobreviver. No intuito de não parecer que "esteja atenuando sua aridez e tirando o que há de pior" o estoico enumera três infortúnios: pobreza, desonra e desprezo (SÊNECA, VI, 1). Ele inclusive diz que "a própria palavra 'exílio' chega ao ouvido muito duramente e fere quem a ouve como triste e execrável por essa convicção radicada em todos: assim decidiu o povo" (SÊNECA, V, 6). A decisão coletiva indica que um membro da sociedade não mais é querido pela mesma por nada ter a contribuir ou por quebrar regras basilares de convivência. Não se exila, por exemplo, um ladrão de galinhas ou um falsificador de moedas, como foi o caso de Iquésio, pai de Diógenes. Trataremos desse assunto mais adiante. De todo modo, há uma medida para aplicação de tal pena. Não podemos esquecer, ainda que se trate de outra sociedade mediterrânea, que Atenas isolava pessoas influentes no meio político por períodos de dez anos pelo ostracismo. Como diferenciá-lo do exílio? Seria um exílio regulamentado e provisório? Enfim, o exílio de Sêneca é uma mensagem clara de que não é bem-vindo, tampouco o querem por lá. Porém, o estoico diz longo em seguida: "mas o sábio rejeita em grande parte os decretos do povo" (Idem), isso porque o critério da maioria "se deixa transportar pela superficialidade e pela opinião corrente" (SÊNECA, VI, 1), postura semelhante à da crítica platônica ao regime democrático que permitiu que leigos condenassem Sócrates injustamente.

"Viver longe da pátria é intolerável" - declara ele de forma retórica no segundo capítulo da sexta parte da consolatio. Ele então empreende refutar esta tese com dois argumentos principais, embora não sejam os únicos. Primeiro, defende o movimento e migração dos homens é natural (SÊNECA, VI, 2-8; VII, 1-10); segundo, ele apresenta uma visão mais naturalista ao diz que, independente de onde estiver, a natureza permanece a mesma (SÊNECA, VIII, 1-6). Sustentando o primeiro argumento, ele aponta inicialmente para Roma, dizendo que "a maior parte dela [a multidão romana] está longe de sua 
pátria”, quer seja pela ambição, pela magistratura, por uma missão confiada, pelo desejo de estudos, entre outros motivos os mais diversos. Afirma ainda, sobre as outras cidades, visto que Roma se poderia chamar cosmopolita, que "não existe nenhuma [cidade] que não tenha sua população em grande parte estrangeira" (Sêneca, VI, 4). Criticando o exílio como punição e sofrimento ele declara que "não encontraremos lugar algum de exílio onde alguém não more por prazer" (Idem) e, comparando o movimento dos homens aos dos astros sempre móveis, justifica a migração afirmando que "todas as coisas rodam e passam: vão de um a outro ponto, como ordena a inexorável lei do mundo" (SÊNECA, VI, 8). Lembra ainda diversas movimentações de povos do passado, conforme exposto a seguir:

Agora, das estrelas volta-te para as coisas humanas: verás que todos os homens e todos os povos, sem exceção alguma, mudaram suas sedes. Que procuravam as cidades gregas nos países dos bárbaros? E as colônias macedônias não meio dos hindus e dos persas? Na Cítia e em todas as terras daqueles povos ferozes e indômitos, veem-se as cidades gregas fundadas nas costas do Ponto: nem a rigidez do inverno perpétuo, nem a índole dos habitantes, selvagens como seu clima, obstaculizaram os emigrantes. Na Ásia Menor há uma multidão de gregos; Mileto fundou em todo o mundo e deu habitantes a setenta e cinco cidades: todo o lado da Itália banhado pelo mar Jônio tornou-se a Magna Grécia. A Ásia deu origem aos etruscos, os tírios (fenícios) habitam a África, os cartagineses, a Espanha, os gregos introduziramse na Gália, os gauleses, na Grécia; os Pirineus não impediram a passagem dos germanos; a volúvel raça humana espalhou-se por todos os caminhos do mundo, mesmo se desagradáveis e desconhecidos. [...] Eterno é o mudar do gênero humano; todos os dias alguma coisa muda em sua esfera; póem-se os alicerces de novas cidades, surgem novos nomes de povos, depois que os precedentes se extinguiram ou foram absorvidos por povos mais fortes. Que mais são essas emigraçóes de povos senão exílios públicos? (SÊNECA, VII, 1-5)

Sêneca também recorda que Roma é consequência de migrações estrangeiras, tendo sido fundada por Enéias de Tróia cujas peripécias são cantadas no célebre épico de Virgílio intitulado Eneida: "o Império Romano reconhece como seu fundado um exilado, fugido pela queda de sua cidade, à procura de terras longínquas por medo dos vencedores, trazidos à Itália pelo Fado com poucos companheiros sobreviventes" (SÊNECA, VII, 6). Fala também da ilha onde ele próprio se encontrava em exílio e dos diversos povos que lá habitaram ou ainda habitavam. Dentre os vários citados, chama atenção o caso dos iberos, povo que, pela descrição de Sêneca, compartilha traços culturais com outros povos como o uso de chapéus e calçados típicos 
dos cantábrios e algumas de suas palavras, visto que "devido a suas relações com os gregos e com os ligúrios, [sua língua] modificou-se profundamente" (Idem, VII, 9).

Além disso, tira de Varrão e Bruto os dois remédios (phármakoi) contra a mudança de lugar. Do primeiro, "pensar que, por toda parta onde formos, teremos ao nosso redor a mesma natureza", enquanto do segundo "pensar que quem parte pode levar consigo suas virtudes". O estoico contraria quem alegue serem ineficazes estes "remédios" afirmando que "se alguém julga ineficaz para consolar o desterrado um só desses dois remédios, deverá reconhecer que juntos são eficazes", afinal, "nos seguem por toda parte as duas coisas mais belas: a natureza comum a todos e a virtude individual" (SÊNECA, VIII, 1-2). Quanto ao segundo argumento para refutar a tese de que "viver longe da pátria é intolerável", é no remédio de Varrão que Sêneca se baseia para sustentá-lo. Tudo é obra daquele que deu forma ao universo, "seja ele o Deus Senhor de Tudo, seja a incorpórea razão, artífice das maiores obras, seja o divino espírito difundido com igual intensidade em todas as coisas" (SÊNECA, VIII, 4). Esta cosmovisão de que tudo faz parte de uma totalidade leva Sêneca a concluir que nada no mundo seria estranho ao homem, visto que ambos seriam partes de uma totalidade absoluta, tal como células de um mesmo organismo.

Entre os confins do mundo não há exílio porque nada daquilo que está dentro dos confins do mundo é estranho ao homem. De qualquer parte o olhar levanta-se igualmente para o céu, a mesma distância separa em qualquer parte as coisas divinas das humanas. Por isso, enquanto meus olhares não se afastarem do espetáculo que os farta; enquanto me for permitido olhar o sol e a lua [...]; enquanto estiver com todas essas coisas e me confundir, tanto quanto é permitido ao homem, com as coisas celestes; enquanto tiver sempre alta a alma, inclinada por sua natureza à contempla dos astros a elas semelhantes - que importa que solo eu pise? (SÊNECA, VIII, 5-6)

Retornemos então ao cinismo de Diógenes, o mesmo que havia sido condenado ao exílio e respondia a quem lhe perguntasse que, na verdade, foi ele quem os condenou a permanecer onde estavam. Musônio indica uma pista que corrobora a investigação de Eric Brown sobre o pioneirismo do cosmopolitismo de Sócrates que, embora vinculado de mais à cidade e seus conterrâneos, mesmo assim via a humanidade como uma categoria unida independente de cultura, credo ou fisionomia. Resgatando a fala de Sêneca sobre o movimento natural de tudo o que existe, notemos a seguinte passagem de Diógenes Laércio sobre o cínico: "Dizendo outra pessoa que o povo de Sinope o condenara ao exílio, Diógenes replicou: $E$ eu o condenei a permanecer onde estava"' (D.L., VI, 49). Paradoxalmente, em outra passagem de Diógenes Laércio (D.L., VI, 38) é relatado que Diógenes dizer ser um homem "sem cidade (ápolis), sem lar, banido da pátria” (D.L., VI, 38). Como poderia ser? 
De que modo poderia Diógenes ser ao mesmo tempo ápolis e kosmopolites? Tanto para complicar ainda mais a questão quanto para apontar uma pista, em outra passagem nos é relatado o seguinte:

Em relação às leis, segundo Diógenes, não é possível a existência de um Estado sem elas. Esse filósofo afirma que sem uma cidade a própria civilização não tem utilidade alguma; a cidade é uma comunidade civilizada e organizada; sem a cidade as leis não tem utilidade; logo, a lei é a civilização. [...] A única organização política correta, dizia ele, é a universal. (LAERTIOS, VI, 72)

Como bem apresenta Zanella, na Grécia clássica "ser cidadão (polites) significava pertencer a uma cidade (pólis), com todas as vantagens e obrigações daquela que formam essa associação". Sobre a resposta de Diógenes, ele comenta que "uma vez que Diógenes não respondeu à pergunta com a resposta esperada e de forma positiva, a saber, de Sinope, sua cidade natal, ele recusava seu dever para com os cidadáos de Sinope assim como o seu direito de ser ajudado por eles". $\mathrm{O}$ autor ressalta que, apesar disso, a resposta do cínico não declara um não pertencimento a cidade alguma (apolites), mas "afirma, na verdade, um pertencimento e a submissão em relação ao universo (kósmos)" (ZANELLA, 2014, p. 168). Ora, se a escola cínica é aquela cuja proposta consiste em se desvincular de qualquer ordenamento artificial (nómos) para levar uma vida de acordo com a natureza (phýsis), então não é por mero acaso que haja um desprezo à ideia de filiação a uma cidade ou comunidade, já que no mundo helenístico a relação entre o homem e sua comunidade pela cidadania é substituída pela relação do homem para com o universo.

\section{Conclusão}

Concluímos então recapitulando o nosso percurso até aqui. De um lado, a visão deturpada pelo romantismo resultava em juízos equivocados quanto às conquistas alexandrinas. Afirmava-se que a monarquia universal era um projeto de Alexandre Magno para além da mera aquisição de terras e bens, conceito este que foi criticado e refutado pelo breve comentário de Peter Green quando este aponta a relação conturbada entre macedônios e gregos para mostrar que o etnocentrismo e a xenofobia não deixaram de existir de uma hora para outra e muito menos era algo desejável. Por outro lado, temos o viés teórico de filósofos que veem o mundo (kósmos) como cidade e defendem que o vínculo real não deve ser o vínculo artificial entre cidadão e pólis, mas, sim, o vínculo natural do indivíduo com o mundo.

Em nossa análise constatamos que, na prática, as relações interétnicas no período helenístico não eram tão harmoniosas quanto se diz por aí. O pan- 
helenismo é dos, entre e para os gregos, independente de um Isócrates dizer a Felipe da Macedônia que considere toda a Hélade sua pátria (Ad Phillippo, $5,127)$. No fundo, Isócrates não faz mais do que convocar um estrangeiro tal como se contrata um mercenário para fazer guerra em seu lugar.

\begin{abstract}
The concept of world-citizenship reemerged during the Enlightenment as part of its multiple political proposals. However, it was in classical Greece that, according to Diogenes Laertios' Lives and others, Diogenes the Cynic first claimed the word kosmopolites. In imperial Rome, the cynical cosmopolitanism was reproduced following axioms of the stoic philosophy by intellectuals like Seneca and Mousonius Rufus. Traditional historians used to understand the Alexandrian campaign as a project of cosmopolis enclosing all people and civilizations of the known world. This paper intends to criticize Hellenistic cosmopolitanism through comparison of its theoretical and factual ways.

Keywords: Cynism, cosmopolitanism, pan-helenism, identity, Classical Greece.
\end{abstract}

\title{
REFERÊNCIAS
}

\section{Documentos textuais:}

ISÓCRATES. To Demonicus, To Nicocles, Nicocles or The Cyprians, Panegyricus, To Philip, and Archidamus. Tradução de George Norlin. Loeb Classical Library, v. 1. Cambridge: Harvard University Press, 1960.

LAERTIOS, Diógenes. Vidas e doutrinas dos filósofos ilustres. Tradução do grego, introdução e notas por Mário da Gama Kury. Brasília: Editora UnB, 2008.

GAIUS MUSONIUS RUFUS. Compilado por Otto Hense. In: HENSE,Otto.

C. Mousonii Rufi Reliquiae. Leipzig: BG Teubner Verlag, 1905.

SÊNECA, Lucius Annaeus. Consolação a minha mãe Hélvia. Tradução e notas de Giulio Davide Leoni. In: Epicuro; Lucrécio; Cícero; Sêneca; Marco Aurélio. Coleção Os Pensadores. São Paulo: Abril Cultural, 1980.

\section{Bibliografia:}

GREEN, Peter. Alexandre, o Grande e o período helenístico. Rio de Janeiro, Objetiva, 2014.

HADOT, Pierre. O que é filosofia antiga?. São Paulo: Edições Loyola, 1999.

LÉVÊQUE, Pierre. O mundo helenístico. Lisboa: Editora 70, 1987.

REALE, Giovanni; ANTISERI, Dante. História da Filosofia Ocidental. Vol. 1. Tradução de Ivo Storniolo. São Paulo: Paulus, 2003.

SOUZA, O. M. de; PEREIRA MELO, J. J.. Reflexões sobre educação e política no pensamento de Epicuro. Inः X Jornada Nacional do HISTEDBR, 2011, Vitória da Conquista - Bahia. Jornada HISTEDBR, 2011.

ZANELLA, Diego. A origem do conceito de cosmopolitismo. Hypnos, São Paulo, v. 32, 2014, p. 166-176. 